\title{
Integrated Management Plan for the Itaquri Lobo Watershed and UHE Carlos Botelho (Lobo/Broa) Reservoir
}

Tund isi, J .G . ${ }^{1}$, Matsumura-Tund isi, T. ${ }^{2}$, Tund isi, J .E. ${ }^{2}$

${ }^{1}$ Feevale University, Novo Ha mburgo, RS.

${ }^{2}$ Instituto Internacional de Ecologia, São Carlos, SP.

Corresponding author: tundisi@iie.com.br

\section{Abstract}

This paper refers to the management plan for the watershed and reservoir of the UHE Carlos Botelho, also known as Lobo/Broa. The management is based on the ILBM Platform Process, that is Integrated Lake Basin Management. It includes three main basin regulations and management: basin water qua lity regula tions; basin infra struc ture development plans; basin water quality plans.

The management plan is based on the scientific and technical developments at the watershed and reservoir since 1971.

Keywords: watershed, reservoir, limnology, management, water resources.

\section{Introduction}

Lobo/Broa reservoir is situated in the Ita queri/Lobo watershed. The watershed and the reservoir have the following characteristic s: La titude: $22^{\circ} 15^{\prime} \mathrm{S}$, Long itude: $47^{\circ} 49^{\prime} \mathrm{W}$; Area of watershed: $230 \mathrm{~km}^{2}$;
Area of reservoir: $7 \mathrm{~km}^{2}$; Mean depth of reservoir: 3.0 meters; Volume of reservoir: $22.000 .000 \mathrm{~m}^{3}$.

The watershed islocated in a region of Savanna vegetation ("cerrado") cover and areas of reforestation with Pinus sp and Eucalyptus sp. 
Clima tologic a I fluc tuations shows higher precipitation during summer, very little precipitation during winter and an a verage of $1.500 \mathrm{~mm}$ of ra infall during the yearconcentrated in the summer months (November to March/April) (TUNDISI, MATSUMURA-TUNDISI, RODRIGUES, 2003).

Wind speed is a round $10 \mathrm{~m} / \mathrm{s}$ during the winter. Due to the shallowness of the reservoir, a permanent mixing occurs in the open water. Retention time is a round 20 days. The reservoir is used for hydropower generation ( $2 \mathrm{MW} / \mathrm{h}$ ); recreation; sport fisheries; to urism; a qua tic sports.

The reservoir has an important economical input for the region rec eiving a round 10.000 tourists in the weekends specially during the summer. Periotto, Tundisi (2013) identified 20 servic es of watershed and the reservoir that a re useful to the human well being and to the biologic al communities of terrestrial and aquatic organisms.

Therefore a management plan for the watershed and reservo ir is essential in order to secure permanently a good soil use, pollution control, adequate water qua lity that will enhance touristic a c tivities with economic impact. The management plan was based on the IBLM Platform Process (NAKAMURA, RAST, 2011).

\section{The management plan}

Figure 1 shows the integrated management plan for the reservoir and the watershed. The main purpose of this paper is to inform and guide the process of watershed and resenoir govemance and the implementation of programs, polic ies and actions in a $n$ integrated and systemic view with a mple participation of the basin communities, sta keholders, with high accountability and responsibility. This management plan is, to a large extent based on the research, planning and monitoring a c tivity ca ried on in the watershed and reservoir since 1971, and in disc ussion with a II munic ipa lities, involved, sta keholders, research workers and The Public Ministry of S. Paulo State dedicated to this a rea (GAEMA) (TUNDISI, MATSUMURA-TUNDISI, RODRIG UES 2003; TUNDISI, MATSUMURATUNDISI, 2013, TUNDISI, 2017).

\section{Discussion and Conclusion}

As reported by Nakamura and Rast (2011) ILBM Platform a ctivities develops a series of a ctivities and steps in the following flows:

- Describe the state of lake/reservoir basin management. Develop a lake/reservoir brief.

- Prepare a database and knowledge bases of data and information from monitoring, reconnaissance, survey, inventory.

- Analyze the existing information to ensure a systemic approach and a integrated overview of ecosystems (watershed and reservoir).

- Integrate ways and means for implement future actions.

- Coordinate stakeholder consultations.

- Evaluate improvements in governance issues. 


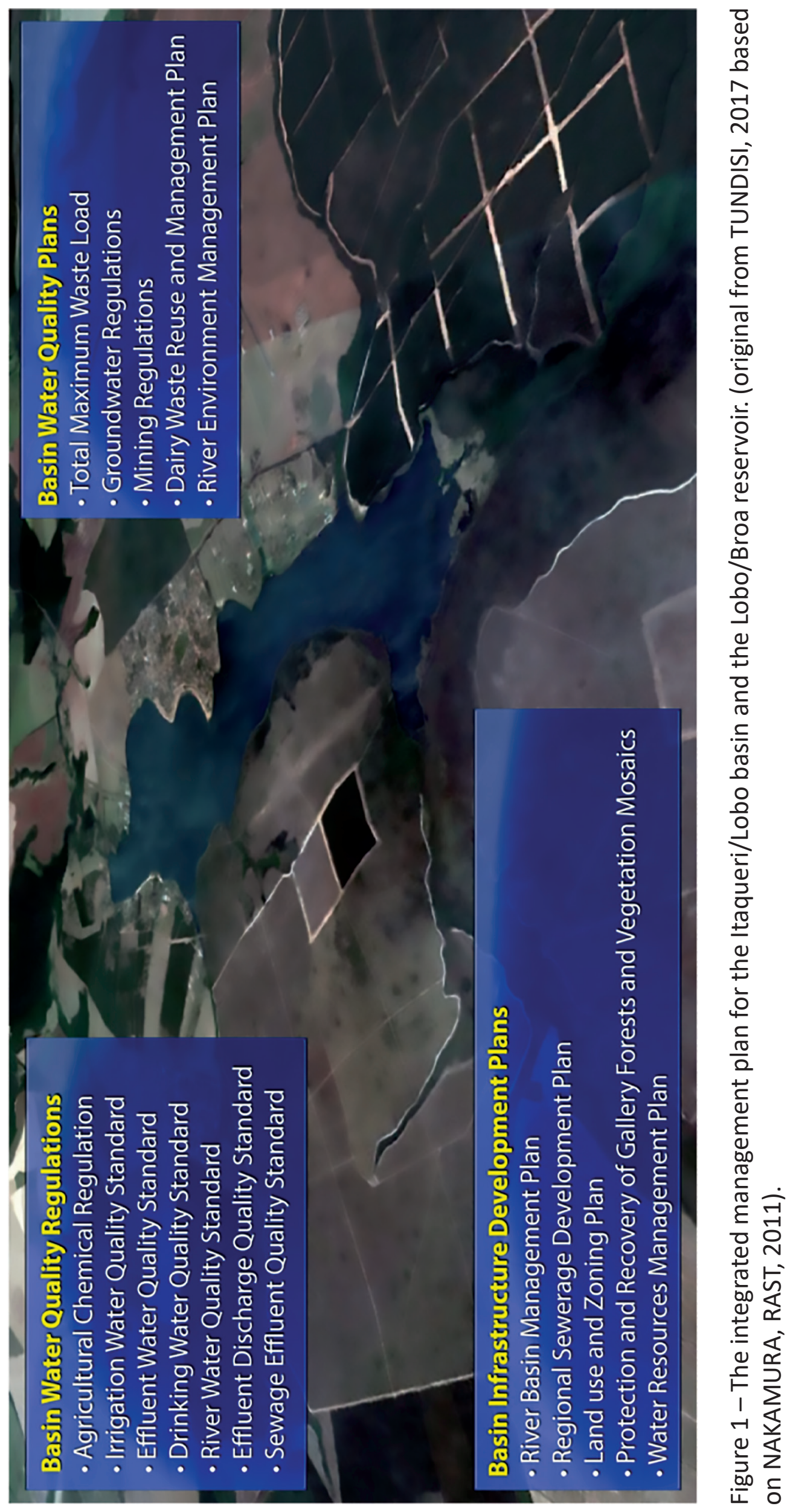


This integrated management plan is complex due to several plans and regulations. Watershed and reservoirs a re complex ecosystems with many interactions, of c lima tologic al, hydrologic al, hidrogeoc hemic al, biologic al and geomorphological process in a dynamic, spatial and temporal succession and fluc tuations. All these complexities were studied at Lobo/Broa reservoir and Itaqueri/ Lobo watershed. Therefore the next step is to promote a sound management

\section{References}

NAKAMURA, M. and RAST, W., 2011. Development of ILBM Platform Process: evolving guidelines through participatory improvement. RCSE. Shiga University and ICEC. 76 pp.

PERIOTTO, N.A. and TUNDISI, J.G., 2013. Ecosystem services of UHE Carlos Botelho (Lobo/Broa): a new approach for management and planning of dams multiple uses. Braz. Journ. Biol., vol. 73, pp. 471-482.

TUNDISI, J.G., MATSUMURA-TUNDISI T. and RODRIGUES S.L., 2003. Gerenciamento e recuperação das bacias hidrográficas dos rios Itaqueri e Lobo e da UHE Carlos Botelho (Lobo/Broa). IIE/IIEGA, ELEKTRO. pp. 54. plan structured in the basic knowledge developed after many years of research (TUNDISI, MATSUMURA-TUNDISI, 2013; TUNDISI, 2017).

\section{Acknowledgements}

The a uthors a cknowledge the fina ncial support of FAPESP-PELD project (2012/51502-3) for the research at the Lobo/Broa reservoir and Itaqueri/Lobo watershed. The support of CNPq for PELD is a lso a c knowledge (Process: 441564/2016).

TUNDISI, J.G. and MATSUMURA-TUNDISI, T., 2013. The ecology of UHE Carlos Botelho (Lobo/Broa) reservoir and its watershed. São Paulo, Brazil. Freshwater Reviews, vol.6, pp. 75-91.

TUNDISI, J.G., 2017. Pesquisas ecológicas de longa duração na bacia dos rios Itaqueri e Lobo e na represa da UHE Carlos Botelho (Lobo/Broa) Itirapina, $S P$, Brasil. Relatório Final - FAPESP, Projeto PELD Pesquisas Ecológicas de longa duração. pp. 82. 